\title{
ANEKA RAGAM PENGETAHUAN LOKAL DAN KREATIFITAS PETANI YANG MENDUKUNG AGROECOPRENEUER RAMAH LINGKUNGAN DI SULAWESI SELATAN
}

\author{
Pawennari Hijjang, Munsi Lampe, dan Muhammad Basir \\ Jurusan Antropologi Fakultas Ilmu Sosial dan Ilmu Politik Universitas Hasanuddin \\ Jln. Perintis Kemerdekaan KM.10 Kampus Unhas Tamalanrea Makassar \\ E-mail :aweunhas@yahoo.com
}

\begin{abstract}
ABSTRAK Indonesia dikenal sebagai negara agraris, tapi ironisnya hampir semua kebutuhan makanan pokok diimpor. Ini perlu diteliti lebih jauh mengapa fenomena ini terjadi. Isu kerusakan lingkungan dan semakin tergerusnya sumber-sumber ekonomi masyarakat seperti biaya produksi dan resiko ber-usahatani semakin tinggi serta ketergantungan petani terhadap penggunaan eksternal input, membuat hasil produksi tidak seimbang dengan pengorbanan yang diberikan. Oleh sebab itu penelitian ini bertujuan untuk mendiskripsikan pengetahuan lokal petani, kreatifitas petani yang dapat membentuk karakter petani yang memiliki pola pikir entrepreneurial. Metode yang digunakan adalah metode kualitatif dengan teknik pengumpulan data wawancara mendalam, observasi, dan fokus group diskusi. Hasil penelitian menunjukkan bahwa pengetahuan lokal diaplikasikan dalam setiap kegiatan pertanian mulai dari penentuan musim dan pemilihan bibit hingga pasca panen dan hasil produksi, untuk membangun petani yang berjiwa agroecopreneur dan arif lingkungan diperlukan akumulasi pengetahuan lokal dan kreatifitas petani, baik yang bersumber dari tradisi lokal maupun yang dari luar secara selektif dalam situasi dan kondisi yang kondusif melibatkan secara aktif semua unsur stakeholder.
\end{abstract}

Kata Kunci: Pengetahuan Lokal, Kreativitas Petani, Pengembangan, Entrepreneur, Arif Lingkungan

\section{VARIOUS LOCAL KNOWLEDGE AND CREATIVITY THAT SUPPORT FARMERS AGROECOPRENEUER ENVIRONMENTALLY FRIENDLY IN SOUTH SULAWESI}

ABSTRACT Indonesia is known as an agricultural country, but ironically almost all basic food needs are imported. This needs to be investigated further why this phenomenon occurs. The issue of environmental degradation and the erosion of the economic resources of society such as the cost of production and the risk of higher farming areas as well as the dependence of farmers on the use of external inputs, making the production is not balanced by the sacrifice. Therefore, this study aimed to describe the local knowledge of farmers, farmer creativity to shape the character of the farmers who have an entrepreneurial mindset. The method used is the method of qualitative research collection techniques in-depth interviews, observations, and focus group discussions. The results of research showed that farmers' local knowledge and creativity applied to any agricultural activities ranging from the determination and selection of seeds to harvesting and post-production, to establish farmer-spirited and wise agroecopreneur necessary environment accumulated local knowledge and creativity of farmers, both from tradition local and external selectively in situations and conditions that are conducive to actively involve all stakeholders element.

Key Words : local knowledge, farmers creativity, development, entepreneur, andecological wisdom

\section{PENDAHULUAN}

Revitalisasi pertanian yang dicanangkan pemerintah dalam memacu peningkatan produksi hasil pertanian dengan menggunakan bahan-bahan kimia sintesis dalam jangka pendek secara kualitas boleh berhasil. Akan tetapi dalam jangka panjang perlu dipikirkan kembali karena disamping aspek kuantitas dan kualitas produksi dan faktor-faktor produksi mulai tergerus, aspek sosial, budaya, lingkungan dan kesehatan semakin terancam. Menurut Vasilikiotis (2000) dalam Massie (2011) yang mengatakan bahwa "teknologi industri komersial yang digunakan saat ini dibidang pertanian untuk memberi makan penduduk dunia bersifat tidak sustainable. Selanjutnya Vasilikiotis mengatakan khusus di negara sedang berkembang teknologi ini tidak mampu menghasilkan kemandirian dan ketahanan pangan bagi penduduknya. Visilikiotis juga mengatakan selain kehilangan unsur hara, salinitas tanah dari saluran irigasi, ketergantungan terus pada penggunaan bahan bahan kimia sintesis sesungguhnya tidak renewable dan jelas juga tidak sustainable. Visilikiotis merujuk pada gerakan green revolution puluhan tahun lalu yang bercirikan sistem pertanian industrial melalui pengembangan benih varietas umggul yang secara efektif menggunakan input dari pupuk kimia secara masif dan pestisida beracun yang berimplikasi pada kerusakan lingkungan seperti kegilangan unsur hara, menurunnya kesuburan tanah, permukaan tanah dan air telah mengalami kontaminasi serta hilangnya keanekaragaman hayati mengakibatkan produktivitas terus menurun (Massie, 2011).

Menghadapi persoalan demikian, rupanya sebagian besar petani kita, bukanlah orang orang yang lantas bersikap pasrah terhadap berbagai persoalan dan kesulitan yang mengancamnya. Sebaliknya, mereka sejak dahulu merupakan individuindividu dan kelompok-kelompok yang tidak habis habisnya berpikir dan tidak mengenal lelah mencari cara pemecahan masalah tersebut. Aplikasi unsur unsur pengetahuan tradisional dan pengetahuan baru secara selektif, adopsi dan modifikasi teknologi pertanian itulah yang banyak ditempuh petani dalam rangka meningkatkan produksi dan mutu berasnya. Dengan demikian, pada saat yang bersamaan petani 
dapat menerima dan mengambil manfaat dari model pengetahuannya dan dapat pula diterapkan oleh kelompok petani lain (Joshi et al., 2004; Merriwej, 1998).

\section{METODE}

Pengetahuan lokal petani dan inovasi di dokumentasikan kemudian disajikan dalam bentuk model pengetahuan yang mudah dipahami. Hal ini dilakukan dengan alasan; (1) untuk mengembangkan potensi pengetahuan dan pola entrepreneurial yang ada, (2) untuk menghindari tergerusnya pengetahuan lokaloleh laju perkembangan pengetahuan yang dinamis.

Pendekatan yang digunakan dalam penelitian ini adalah sistem berbasis pengetahuan (SBP atau lebih dikenal dengan KBS/ Knowledge Base System) (Sinclair dan Walker, 1998). Kom-pilasi pengetahuan lokal dilakukan dengan menginventarisasi informasi pengetahuan lokal petani, kemudian mendokumentasikannya dalam bentuk pernyataan-pernyataan (unitary statement), dan merangkaikan pernyataan tersebut ke dalam suatu hubungan sehingga menunjukkan deskripsi model pengetahuan lokal petani dan masyarakat setempat.

Proses inventasisasi data yang disertai dengan proses artikulasi pengetahuan lokal dilakukan melalui penelitian etnografi dengan teknik pengumpulan data pengamatan langsung dan wawancara dengan informan tentang pemahaman mereka terhadap komponen dan fungsi ekosistem pertanian, usaha tani, serta interaksi yang terjadi di dalamnya. Dari proses ini diperoleh suatu deskripsi yang komprehensif tentang praktek dan tindakan dalam mengelola pertanian

Data pengetahuan lokal petani dikompilasi dari hasil wawancara mendalam terhadap sejumlah orang yang dipilih berdasarkan pengetahuan yang mereka miliki. Usaha mengenai pengelolaan pertanian dan pola entrepreneurial digali melalui serangkaian pengamatan, diskusi terfokus dan wawancara mendalam baik secara individual maupun kelompok terhadapa sejumlah petani yang mempunyai pengalaman langsung. Penelitian ini dilaksanakan di Sidenreng Rappang, Gowa, dan Tana Toraja. Lokasi ini dipilih karena ketiga tiganya merupakan penghasil beras utama di Sulawesi Selatan.

\section{HASIL DAN PEMBAHASAN}

Indonesia dikenal sebagai Negara agraris yang ditandai dengan potensi pertaniannya. Sejak beriburibu tahun lalu hingga dewasa ini para petani menjadi produser pengetahuan, inovator dan eksperimenter utama dalam dunia pertanian bahan makanan (Amanor, 1993; Conway, 1998). Kekayaan varitas padi yang dibudidayakan oleh komunitas petani dari etnis yang berbeda-beda di dunia, termasuk Indonesia, membuktikan kemampuan kreativitas-inovatif mereka, baik dalam proses akumulasi unsur-unsur pengetahuan yang aplikatif, maupun pilihan varitas dan teknik budidaya tanaman secara selektif. Berbagai studi empirik mengenai fenomena budaya pertanian padi pada komunitas petani seperti dilakukan antara lain oleh Winarto (2004) di Kabupaten Subang Jawa
Barat dan studi banding yang dilakukannya pada petani di Indonesia (Jawa dan Sumatera), Vietnam, dan Kamboja (2004); Vayda dan Indah Setyawati (1998) di Jawa; Semiarto Aji Purwanto di Kabupaten Serang Jawa Barat (1998).

Landasan pemikiran tentang proses kreasi, akumulasi pengetahuan, dan aplikasi teknik budidaya pertanian, khususnya pertanian padi, dapat dilacak dan merujuk pada perspektif evolusionisme budaya, terutama metodologi analisis evolusi multilineal dari Steward (1955), yang studinya juga mencakup evolusi pertanian padi di pusatpusat pembudidayaan di dunia. Dalam empat tahap perubahan besar yang evolusionis dari peradaban masyarakat manusia (inovasi pertanian, diversifikasi pekerjaan, pemerintahan pusat, dan stratifikasi sosial) yang dianalisis oleh Steward, ternyata inovasi pertanian mengawali proses perkembangan dan perubahan besar peradaban masyarakat manusia yang menyolok tersebut (lihat juga Haviland, 1985: 306-314). Faktor utama dalam perkembangan budaya pertanian dari model ekstensifikasi ke intensifikasi, menurut analisis evolusionis budaya tersebut, ialah irigasi yang berfungsi dengan baik. Sebab dengan sistem irigasi dan waduk, yang antara lain dibangun oleh orang Sumeria di zaman dahulu, maka petani dapat melaksanakan kegiatan usaha tani terlepas dari kondisi musim. Diasumsikan bahwa melalui keberhasilan pertanian, dalam arti ketersediaan bahan pangan beras, maka masyarakat menjadi makmur dan meningkatkan jumlah penduduk.

Selain itu, dalam rangka pemberdayaan masyarakat khususnya di Indonesia yang agraris, maka harus diingat bahwa masyarakat tani Indonesia adalah masyarakat yang memiliki keragaman etnis dan budaya. Hal ini berarti bahwa pengembangan yang menghendaki penyeragaman satuan sosial dan budaya seperti halnya paradigma revolusi hijau tentu berpotensi mengikis pranata lokal, menumbuhkan konflik, dan ketergantungan sosial pada sumbersumber eksternal seperti yang banyak terjadi selama ini. Agar hal tersebut tidak terjadi lagi, maka peran negara maupun pemerintah harus dikurangi, sebaliknya peran masyarakat ditingkatkan (Lampe dkk, 2007; Hijjang dkk, 2012, 2013)

\section{Unsur-Unsur Pengetahuan Lokal Dan Krea- tivitas Petani}

Penelitian yang dilakukan di Kabupaten Gowa, Kabupaten Sidrap dan Kabupaten Tana Toraja ditemukan beberapa hal bahwa pengetahuan petani yang menyangkut pengelolaan usaha taninya umumnya seperti petani didaerah lain. Menyangkut pengetahuan lokal yang unik tidak banyak ditemukan. Hanya beberapa hal yang menyangkut perlakuan-perlakuan petani terhadap lahan dan tanaman padi yang merupakan kreativitas petani itu sendiri. Berikut ini gambaran mengenai pengetahuan lokal dan kreativitas petani berdasarkan pada tiap lokasi penelitian (Lampe 2007, dkk; Hijjang dkk, 2012; 2013). 
Penguatan pada komunitas petani pada dasarnya harus berbasis pada kemampuan petani itu sendiri, sedangkan unsur dari luar diharapkan dapat mendukung petani dapat mandiri dan bebas dari ketergantungan. Hasil wawancara dengan informan yang dikompilasi dengan hasil penelitian Lampe (2007; 2009) mengatakan bahwa dalam kerangka penguatan petani maka perlu pemahaman berupa unsur-unsur pengetahuan lokal dan kreativitas petani sehingga dapat memberikan konstribusi berupa pencapaian hasil yang berkualitas sebagai berikut;

(1) Kualitas beras dapat dilihat dari kondisi fisik beras yang bulat (selendris), tidak patah, putih bersih dan mengkilap. Ini pun juga menjadi tolak ukur beras berkualitas yang diinginkan oleh BULOG, demikian ungkapan dari Yahya (seorang pengusaha penggilingan beras). Namun demikian tolak ukur seperti itu juga masih ditambah dengan kriteria apakah beras tersebut enak dimakan. Pada tingkat petani beras berkualitas terwujud jika gabahnya berkualitas adalah gabah yang berat, bulat dan isinya padat dan rendimennya tinggi.

(2) Pengetahuan mengenai musim tanam yang akan dihadapi merupakan titik awal dari proses usaha tani. Bagi petani musim tanam terbagi dalam dua musim yaitu musim rendengan dan gadu. Penanaman secara serentak adalah strategi yang digunakan untuk mengantisipasi supaya tikus menyerang secara merata dan menyebar sehingga dampaknya tidak terlalu parah. Kalau hal ini tidak dilakukan maka akan ada tanaman yang mengalami rusak parah karena tikus biasanya menyukai tanaman yang lebih muda. Selain itu perbedaan dari kedua musim ini ditandai dengan jumlah produksi yang berbeda secara signifikan. Pada musim tanam rendengan produksi lebih rendah, hal ini terjadi akibat dari banyaknya hama dan penyakit dari mu-sim tersebut, dan sebaliknya pada musim gadu biasanya akan lebih baik karena terkait dengan gangguan hama dan penyakit juga berkurang.

(3) Pemilihan bibit untuk disemaikan tergantung pada keinginan dari petani dengan pertimbangan: Pertama, pemilihan bibit didasarkan pada pengalaman tahun sebelumnya apakah bibit tersebut memberikan hasil panen yang memuaskan atau tidak. Kedua, keinginan untuk mendapatkan beras yang enak untuk makanan sehari-hari. Ketiga, memilih bibit yang mempunyai daya tahan terhadap penyakit dan hama tanaman. Keempat, memilih bibit yang dianggap sesuai dengan musim tanam yang akan berlangsung. Misalnya, diperkirakan oleh petani bahwa musim tanam yang akan datang hujan akan cepat turun, sehingga diupayakan panen sebelum turun hujan, ini berarti bibit yang ditanam adalah bibit yang jangka waktunya antara penanaman dan panen sesuai dengan waktu yang dibutuhkan. Seperti dikemukakan informan, bahwa musim tanam yang akan datang kemungkinan hujan akan turun sekitar bulan Maret, jadi seharusnya petani sudah mulai pengolahan lahan pada awal November sehingga panen dapat dilakukan sebelum musim hujan.

(4) Petani pada umumnya sudah menggunakan traktor tangan untuk membantu proses pembajakan sawah. Setelah empat sampai tujuh hari pembajak datang dan mulai memecahkan tanah, hingga sawah nampak rata, tidak ada lagi lempengan-lempengan tanah yang berukuran besar, yang ada hanya lumpur yang siap untuk diratakan. Lahan diupayakan supaya rata dalam semua areal persawahan karena pada bagian yang masih tergenang air atau pada bagian yang kering biasanya rawan terkena hama. Penggunaan metode penanaman yang digunakan terkait dengan kondisi persawahan dan sekaligus perlakuan terhadap lahan persawahan. Sistem tanam pindah ini memiliki keunggulan pada sawah yang berada pada wilayah yang rendah dan selalu tergenang, karena benih yang ditanam dapat beradaptasi dengan baik. Namun dari sisi biaya yang digunakan lebih besar yaitu upah buruh tanah sebesar 600.000 rupiah per hektar, selain rentang waktu yang digunakan dari persemaian hingga penanaman lebih lama 15 hari dibandingkan dengan metode tabela.

(5) Pemeliharann tanaman merupakan rangkaian selanjutnya dari sejumlah perlakuan terhadap lahan dan tanaman padi. Perlakuan tanaman pada tahap awal berbeda antara sistern tanam pindah dan sistem tabela (tanam benih langsung). Sistem tanam pindah perlakuan terhadap tanaman dimulai dari masa perse-maian, dimana gabah yang hendak disemaikan direndam dalam air selama dua malam. Selanjutnya ditiriskan dan dimasukkan dalam wadah kemudian ditutup. Setelah dua atau tiga hari. Kemudian akan muncul kecamba-kecamba yang berwarna putih dan benihpun siap untuk disemaikan. Perlakuan ini pun dilakukan terhadap benih yang akan di tabela. Pada sistem tanah pindah bibit yang disemaikan dipelihara selama kurang lebih 1 bulan dan kemudian dipindahkan untuk ditanam. Sedangkan pada sistem tabela benih tadi langsung ditanam dengan menggunakan alat penanam yang bisa diatur sehingga jumlah benih dapat ditaburkan secara teratur.

(6) Penggunaan pupuk bagi petani sudah merupakan kewajiban jika ingin mendapatkan hasil yang baik, karena menurut mereka kondisi tanah pertanian sudah kurus sehingga harus selalu dipupuk. Pemakaian pupuk oleh petani tergantung dari kebutuhan dan hal itu sudah dapat diidentifikasi oleh petani dengan melihat kondisi tanaman dan kondisi tanah. Kebutuhan pupuk berbeda pada setiap wilayah, misalnya pada daerah yang tanahnya kelihatan berpasir membutuhkan pupuk yang banyak dibandingkan daerah yang tanahnya lebih liat dan berlumpur. Selain itu kondisi tanaman merupakan salah satu hal yang dipertimbangkan oleh petani untuk melihat kebutuhan pupuk oleh tanaman tersebut.

(7) Jenis-jenis hama dan penyakit tanaman pada dasarnya serupa dengan hama tanaman padi lainnya diberbagai daerah dan penggunaan pestisida pun sesuai yang ada dipasaran dan dianggap paling efektif dalam mengatasi hama tanaman tersebut. Selain itu petani 
menggunakan cara untuk menentukan jenis pestisida paling tepat dengan cara menangkap hama yang kemudian diberikan cairan pestisida yang akan digunakan. Hasilnya kemudian menentukan jenis pestisida yang dipilih.

(8) Panen dilaksanakan ketika padi sudah mencapai umur padi sesuai dengan jenis bibit yang ditanam. Padi yang siap dipanen memiliki ciri-ciri tertentu, misalnya daunnya sudah menguning, sebagian juga kering, buahnya merunduk dan biji-biji padi sudah mengeras. Proses panen dilakukan dengan menggunakan sabit dan perontokannya menggunakan dros. Pengetahuan petani dalam hal pengolahan pasca panen relatif terbatas, karena memang mereka sudah tidak memperhatikan hal tersebut. Gabah hasil produksi yang langsung dibeli oleh pedagang dan nantinya pedagang yang juga biasanya pemilik penggilingan yang menyiapkan gabah tersebut untuk digiling. Peran DOLOG hanyalah menerima beras hasil penggilingan dari para pengusaha penggilingan. Selama tidak ada petani yang berhubungan langsung dengan DOLOG se-hingga harga pembelian ditingkat petani masih dikendalikan oleh pedagang meskipun ada harga standar dari pemerintah. Selain dijual kepedagang petani juga menyimpan gabah untuk konsumsi keluarga. Menurut Lampe dkk (2007; 2009) mekanisme pemasaran biasanya melalui pedagang pengumpul yang langsung membeli di persawahan, dan ada juga yang langsung ke pedagang besar pemilik penggilingan, dan selanjutnya pemilik penggilingan menjual beras ke DOLOG.

\section{Teknologi Usaha Tani Ramah Lingkungan}

Pengembangan teknologi yang murah, mudah, praktis dan bernilai manfaat dapat dicerna oleh masyarakat lokal akan mendukung peningkatan kuantitas dan kualitas hasil produksi. Pengetahuan dan teknologi tersebut dapat digali dari potensi masyarakat setempat maupun diadopsi dari luar. Misalnya menggunakan pemanfaatan sampah dari daun dan buah-buahan, rumput, jerami dan lain sebagai bahan kompos untuk mengurangi penggunaan pupuk kimia. Penggunaan merica, daun bawang, tuba, daun surian, cabe dan tanaman-tanaman lainnya yang memiliki bau yang keras sebagai pestisida pengganti pestisida pabrikan. Untuk mempermudah proses pengembangan ini peran pemerintah sangat vital, khususnya dalam mengkomunikasikan pengetahuan dari satu daerah ke daerah lain, dari satu komunitas petani ke komunitas petani lainnya sehingga pengetahuan dan teknologi dapat terso-sialisasi dan diaplikasikan oleh masyarakat petani, yang tujuan akhirnya ialah peningkatkan agribisnis beras petani yang berkualitas.

Pengembangan pengetahuan dan teknologi yang ramah lingkungan, adaptif dan produktif mutlak harus dilaksanakan dengan mempertimbangkan bahwa penggunaan teknologi berupa pestisida, pabrikan, pupuk kimia, dan penggunaan yang tidak sesuai ataupun sesuai peruntukannya dapat berakibat pada rusaknya ekosistem dan dampak negatif bagi kesehatan manusia. Untuk itu perlu upaya melembagakan pengetahuan lokal dan peningkatan daya kreativitas petani untuk menjadi kerangka acuan bagi petani-petani lainnya dalam menjalankan usaha taninya. Sangat penting untuk mengidentifikasi unsurunsur pengetahuan, tekonologi, praktik-praktik khusus yang masih diaplikasikan petani untuk kemudian dikaji secara ilmiah yang memberikan penjelasan logis dari hal tersebut, kemudian dijadikan pengetahuan baru dalam rangka peningkatan produktivitas pertanian dan kesejahteraan petani.

Adopsi teknologi yang berfungsi mempermudah pekerjaan pengolahan lahan tentu tidak diterima begitu saja, tetapi terlebih dahulu perlu dilakukan kajian kecocokannya terhadap wilayah persawahan dan kondisi alam setempat. Misalnya, adopsi teknologi traktor dari China tidak selamanya bisa langsung digunakan di daerah pertanian Sulawesi Selatan, namun oleh petani teknologi tersebut masih perlu dimodifikasi sehingga dapat dimanfaatkan selayaknya di daerah ini. Proses dan kondisi seperti inilah disebut proses adaptasi dan kebertahanan suatu pengetahuan lokal atau teknologi yang dapat menunjang bagi peningkatan produktivitas.

\section{Analisis Pengetahuan Lokal Yang Mendukung Agroecopreneur Ramah Lingkungan}

Dari hasil penelitian diketahui unsur-unsur pengetahuan lokal yang bertahan dan diaplikasikan petani seperti tatacara pemilihan benih, gabah dan beras berkualitas, musim tanam, siklus dan kondisi pertumbuhan tanaman, buah padi yang sehat, bahan pupuk organik, jenis-jenis ha-ma dan penyakit tanaman, musuh alami, bahan obat/racun alamiah, dan lain-lain. Adapun teknologi dan praktik tradisional yang bertahan dan diaplikasikan petani ialah teknik pengolahan lahan yang sistematik dengan bajak, cangkul, meratakan, menginjak-injak jerami, teknik pembibitan, teknik tanam pindah, pemeliharaan tanaman (penyulaman, penyiangan, pengaturan air, penggunaan pupuk organik, penanganan hama dan penyakit tanaman), teknik panen, dan pasca panen, pemasaran, budidaya ikan di sawah. Di-asumsikan bahwa sistem-sistem tradisional (pengetahuan, teknologi, dan praktik) merupakan hasil proses kreasi dan modifikasi secara lokal sebagai respon terhadap ketersediaan potensi-potensi internal dan eksternal sejak dahulu.

Unsur-unsur pengetahuan, teknologi, dan praktik tradisional tersebut masih diterapkan petani karena fungsinya masih dianggap efektif dan unsur-unsur baru yang diadopsi dari luar belum dapat menggeser sebagian besar dari fungsi utamanya. Efektivitas pemungsian tersebut hanya dapat ditunjukkan dengan pengakuan petani bahwa dengan aplikasi sistem-sistem tradisional tersebut, maka mereka dapat melangsungkan kegiatan usaha taninya dan mendapatkan sumber penghidupan utama dari situ sejak dahulu sampai sekarang.

Terdapat beberapa praktik tradisional yang signifikan sebagai kreasi lokal dalam merespon peluang musim pemilihan bibit, pengolahan lahan, dan bahan pupuk alam. Dalam pemanfaatan masa transisi, keempat masyarakat tani yang diteliti menggunakan pola-pola yang berbeda-beda dan signifikan bagi perolehan tambahan pendapatan ekonomi keluarga petani. 
Misalnya, petani Kelurahan Manisa memiliki pola panen padi transisi dari musim ase bare, ke ase taung atau sebaliknya; petani Desa Manjalling mempunyai pola musim tanam palawija dalam masa transisi dari musim rendengan ke musim gadu; dan petani Lembang Kaero dan Lembang Buntu La'bo' memanfaatkan masa transisi dari musim parepentaunan ke musim pare alla' untuk pemeliharaan ikan mas. Bagi petani Kelurahan Manisa, signifikansi dari pola musim panen ketiga ialah penghasilan berupa gabah atau beras. Bagi petani Desa Manjalling, ialah hasil panen palawija, di samping itu menurut keterangan petani, batang dan daun serta akar-akar yang telah membusuk dapat menambah unsur hara tanah, yang pada gilirannya menyumbang kepada peningkatan ke-suburan tanaman padi pada musim berikutnya. Demikian halnya di Lembang Kaero dan Lembang Buntu La'bo', petani mendapatkan panen ikan mas untuk dijual, sementara ikan-ikan lain dan belut dimanfaatkan oleh masyarakat kampung secara bersama. Menurut keterangan dari petani, budidaya ikan juga memberi pengaruh positif bagi kesuburan lahan, lagi pula memudahkan penggarapan karena tanah dalam petakan senan-tiasa dalam kondisi lembek (Lampe dkk, 2007; Hijjang dkk, 2012, 2013).

Dalam hal pemilihan bibit, ukuran kualitas fisik dan pertimbangan lokal tradisional relatif sama pada keempat masyarakat yang diteliti, meskipun pilihan jenis-jenis padi darimanan blbit diambil bisa berbedabeda di antara petani. Misalnya, petani Tana Toraja mempunyai pilihan yang kaya tentang jenis padi unggul dan padi tradisional. Informan petani dari keempat lokasi menyatakan bahwa pilihan bibit yang tepat merupakan sarah satu penentu utama bagi keberhasilan panen nantinya.

Dalam hal pengolahan lahan secara tradisional, kedua masyarakat tani Manisa dan Manjalling menunjukkan kesamaan, dengan kenyataan di lokasi pertama tahap-tahap kegiatannya lebih sistematik dan rapih. Adapun, di lokasi ketiga, petani Tana Toraja mempunyai praktik yang unik berupa menginjakinjak tanah pada bagian yang lembek-berlumpur dengan maksud menenggelamkan jerami dan rumputrumput dan meratakan tanah. petani tahu betul bahwa jerami dan rumput-rumput yang membusuk nantinya menyumbang kepada tingkat kesuburan tanah.

Mengenai pupuk alamiah, para petani di keempat lokasi tahu manfaat dan kelebihannya, namun pada tingkat aplikasinya menunjukkan perbedaan, baik dalam bentuk dan variasi maupun frekuensinya. Petani Kelurahan Manisa masih jarang sekali menggunakan pupuk organik karena pembuatan yang rumit berat, dan mahal harganya. Sebagian petani Desa Manjalling sering menggunakannya (berbagai bahan) namun dalam jumlah yang sangat terbatas. Petani Tana Toraja di kedua lokasi mengetahui cukup banyak bahan pupuk organik lokal, namun sangat sedikit yang dipraktikkan. Praktik berkaitan pemupukan alamiah yang umum dilakukan petani di sini ialah penggunaan jerami dan rumput-rumput dengan cara menenggelamkan ke dalam lumpur, menumpuk di sudut-sudut petakan sawah dan di pematang, dan menyebankannya ketika sudah membusuk. Bagi keluarga petani yang memelihara kerbau, babi, dan ayam buras, mereka sering juga memanfaatkan kotoran hewan tersebut bagi kesuburan tanaman padinya.

Kebanyakan petani di keempat lokasi mempraktikkan pembasmian hama dan penyakit tanaman secara tradisional, seperti walang sangit, ulat grayak, penggerek batang, keong mas, dan tikus. Khusus di Tana Toraja, burung pipit masih selalu dianggap hama berbahaya. Di Kelurahan Manisa khususnya, penyakit tungdro (cella' pance) merupakan penyakit paling berbahaya yang sering melanda tanaman padi. Di sini, petani merasa sangat sulit mengatasi kemunculan pe-nyakit padi tersebut. Mengenai keong mas, petani dari keempat lokasi, terutama petani Tana Toraja di kedua Lokasi menganggap hama tersebut di samping berbahaya, juga menjadi pembantu petani dalam membersihkan tanaman dari rumput-rumput liar.

\section{SIMPULAN}

Unsur-unsur pengetahuan, teknologi, dan praktik tradisional petani masih diterapkan petani karena fungsinya masih dianggap efektif dan unsur-unsur baru yang diadopsi dari luar belum dapat menggeser sebagian besar dari fungsi utamanya. Efektivitas pemungsian tersebut ditunjukkan dengan pengakuan petani bahwa dengan aplikasi sistem-sistem tradisional tersebut, maka mereka dapat melangsungkan kegiatan usaha taninya dan mendapatkan sumber penghidupan utama sejak dahulu sampai sekarang. Secara akademik, hasil penelitian ini memperkuat pentingnya teori-teori antropologi ekologi dalam pembangunan berkelanjutan yang ramah lingkungan. Secara praktis, hasil penelitian ini menambah referensi bagi pengambil kebijakan untuk pengambilan keputusan berkenaan dengan pertanian.

\section{DAFTAR PUSTAKA}

Amanor K.J., Wellard K., de Boef, W. dan Bebbington, A. 1993. Introduction. Dalam Cultivating Knowledge: Genetic Diversity, Famer Experimentation and Crop Research (Walter de Boef, Kojo Amanor, Kate Wellard, dan Anthony Bebbington, eds), London, Intermediate Technology Publication, pp. 1 - 13.

Conway, G. 1998. The Dubly Green Revoluition: Food for All in the $21^{\text {st }}$ Century, Cornell University Press, New York.

Haviland, W.A. 1985. Antropologi (Jilid 1), Penerbit Erlangga, Jakarta.

Hijjang, Pawennari, dkk. 2008. Revitalisasi NilaiNilai Kearifan Lingkungan yang Menunjang Pembangunan Berkelanjutan di Jayapura, Provinsi Papua. Hasil Penelitian Hibah Kompetensi Batch I, 2008. Dibiayai oleh DP2M DIKTI.

Hijjang, Pawennari, dkk. 2012. Penguatan Pengetahuan Lokal dan Kreativitas Petani yang Mendukung Teknologi Usaha Tani dan Pengembangan Agroecopreneur Ramah Lingkungan di Sulawesi Selatan dan Sulawesi Utara. Hasil penelitian 


\section{MP3EI DP2M DIKTI.}

2013. Penguatan Pengetahuan Lokal dan Kreativitas Petani yang Mendukung Teknologi Usaha Tani dan Pengembangan Agroecopreneur Ramah Lingkungan di Sulawesi Selatan dan Sulawesi Utara. Hasil penelitian MP3EI DP2M DIKTI.

Joshi, L; Schalenbourg, W; Johansson, L; Khasanah, N; Stefanus, E; Fagerstrom, M.H. and M. van Noordwijk. 2004. Soil and Water Movement: Combining Local Ecological Knowledge With that of Modelers When Scalling up From Plot to Landscape Level. In van Noordwijk, M; Ong C.K and G. Cadish (eds). Belowground Interactions in Tropical Agro-ecosystem. CABI, UK.

Koentjaraningrat. 1990. Pengantar Ilmu Antropologi, Rineka Cipta, Jakarta.

Lampe, Munsi, 2007, dkk. Kajian Teknologi Usaha Tani Padi: Menggali Pengetahuan Lokal Yang Mendukung Agribisnis Beras Berkualitas di Kawasan Lumbung Padi. Kerjasama LP2M UNHAS dengan BALITBANGDA Provinsi Sulawesi Selatan.

2009. Menggali Pengetahuan Lokal dan Kreatifitas Petani yang Menunjang Dinamika Pertanian di Kawasan Lumbung Padi: Suatu Komparatif Petani di Kabupaten Sidrap dan Kabupaten Maros Provinsi Sulawesi Selatan. Dibiayai oleh DIPA UNHAS.

Massie, James DD, 2011. Analisis Keputusan Pengembangan Manajemen Usahatani Padi Sawah Berkelanjutan bagi Petani di Kabupaten Minahasa Tenggara, Provinsi Sulawesi Utara. Penelitian Disertasi (tidak dipublikasikan).

McCay, B.j. 1978.System Ecology, People Ecology, and the Anthropology of Fishing Communities, Human Ecology, Vol. 6. No.4: 397-422.

Marrewij, A. V, 1998. Three Definitions Of Indige- nous Knowledge. Indigenous Knowledge and Development Monitor. Vol 6, Issue 3.

Pontius, J; R. Dilts; and A, Bartlett. 2A02. From Farmer Field School to Community IPM : Ten Years of IPM Trainng in ASIA. Bangkok: Food and Agriculture Organization of United Nations Regional Officer For ASIA and the Pacific.

Purwanto, Semiarto Aji. 2004. Menanam Padi: Kajian Pengambilan Keputusan Petani dalam Menentukan Varitas padi, Majalah Antropologi Sosial dan Budaya Indonesia UI, Jakarta, No. 55: 69-83.

Sinclair, F.L; and D.H. Walker. 19981. A Utilitarian Approach to the Incorporation of Local Knowledge in Agroforestry Research and Extension. L.E. Buck; J. P. Lassoie dan E.C.M. Fernandes (Eds), CRC Press.

Steward, Julian. 1955.Theory of Culture Change: The Methodorogy of Multilinear Evolution, Urbana, chicago, London: University of Illionis Press.

Vayda, A.P. dan Indah Setyawaty. 1998.Cuestions About Culture Related Considerations in Research on Cognition and Agro Ecological Change. Majalah Antropologi Sosial dan Budaya Indonesia, UI, Jakarta, No. 55: 44-52.

Vayda, A.P. dan B.J. McCay. 1975.New Direction in Ecology and Ecological Anthropology, Annual Review of Anthropotogy, No. 4: 293-306.

Warren, D. Michael, 1980.Indigenous Knowledge and Devetopment, Monitor Vol 1, No.1: 2-4.

Winarto, Y.T. 2004. "The Evolutionary Changes in Rice-Crop Farming: Integrated Pest Management in Indonesia, Cambodia, and Vietnam", Tonan Ajia Kenkyu (Southeast Asian Studies) Vol. 42, No. 3, December 2004. 